\title{
Geographic variability of sardine growth across the northeastern Atlantic and the Mediterranean Sea
}

\author{
A. Silva ${ }^{a},{ }^{\star}$, P. Carrera ${ }^{b}$, J. Masséc, A. Uriarte ${ }^{d}$, M.B. Santos ${ }^{e}$, P.B. Oliveira ${ }^{a}$, E. Soares ${ }^{a}$, C. \\ Porteiro $^{\mathrm{e}}$ and Y. Stratoudakis ${ }^{\mathrm{a}}$
}

\footnotetext{
a Instituto de Investigação das Pescas e do Mar (INIAP-IPIMAR), Av. Brasília s/n, 1449-006 Lisboa, Portugal

${ }^{\text {b }}$ Museo do Mar de Galicia, Avenida Atlántida 160, 36280 Vigo, Spain

${ }^{c}$ IFREMER, Rue de l'lle d'Yeu, BP 21105, 44311 Nantes Cedex 3, France

d AZTI, Tecnalia/Itsas Ikerketa Saila, Herrera Kaia Portualde z/g, 20110 Pasaia (Gipuzkoa), Spain

e Instituto Español de Oceanografía (IEO), Centro Oceanográfico de Vigo, Apdo. 1552, 36280 Vigo, Spain
}

*: Corresponding author : A. Silva, email address : asilva@ipimar.pt

\begin{abstract}
:
This study describes broad-scale spatial variations in sardine growth across the northeastern Atlantic and Mediterranean waters using opportunistic samples collected in recent years. More detailed information on spatial, decadal and seasonal growth variations is provided for the Iberian-Biscay region using data collected in acoustic surveys since the mid-1980s. Growth curves are fitted to annual or monthly length-at-age data using a robust Von Bertalanffy model; parameters for recent samples are compared with literature information using an auximetric plot while differences between areas within the Iberian-Biscay region are tested by log-likelihood ratio tests. Sardine growth performance is generally lower in the Mediterranean and declines across the northeastern Atlantic from the English Channel to north Morocco but increases sharply off Mauritania. Lower growth of Mediterranean sardines is possibly associated to the overall oligotrophy of this Sea while differentiation from the Atlantic is likely sustained by reproductive isolation between populations from the two areas. Within the northeastern Atlantic, size- and age related migrations may partly explain differences in maximum length/age and mean length-at-age between neighbouring areas but the broad-scale latitudinal decline in growth is consistent with adaptation to the north-south decline in seasonal temperature gradients and to the annual cycles of plankton production. Within the Atlantic Iberian waters, sardine grows and improves in condition during spring and summer when the allocation of energetic resources for gonad development cease, temperature is close to the annual maxima and plankton production is high. Variation in sardine length-at-age and growth within the Atlanto-Iberian stock area has implications for stock structure and needs to be taken into account in the calculation of weight and maturity-at-age for assessment purposes. No evidence of broad temporal changes in sardine growth within the Iberian-Biscay region is obtained.
\end{abstract}

Keywords: Sardina pilchardus; Growth; Spatio-temporal variation; Iberian-Biscay region 


\section{Introduction}

The sardine (Sardina pilchardus) is a small pelagic clupeoid distributed in the northeastern Atlantic from the North Sea to Senegal and throughout most of the Mediterranean Sea (Parrish et al., 1989). It has high commercial importance, being targeted by purse-seine fisheries across most of its distribution area and by pelagic trawlers mainly within the African waters. Sardine abundance and fishing intensity are generally lower in the Mediterranean than in the Atlantic waters (GFCM, 2006). Within the northeastern Atlantic, the largest populations are situated off northwestern Africa, while the second most important area spans the Iberian - Biscay waters (from northern France to the Gulf of Cadiz) (FAO, 2004; ICES, 2006). For assessment and management purposes, eight sardine stocks are considered across the Mediterranean Sea, the most abundant and productive ones being located off northern Spain and the Gulf of Lyons (GFCM, 2006). Three sardine stocks are considered off the Atlantic coast of western Africa (FAO, 2004); the largest of these stocks, the central stock, shows acoustic biomass estimates between 1 and 5 million tons and annual landings of 600 thousand tons in recent years. Across the Iberian - Biscay region, sardine is mainly distributed off the western Portuguese waters and in the French Gulf of Biscay (ICES, 2006). A single sardine stock is considered in the European Atlantic waters for assessment and management, the Atlanto - Iberian stock, delimited by the French/Spanish border in the north, and by the Strait of Gibraltar in the south (ICES, 2006). Catches from this stock have fluctuated around 95 thousand tons in recent years and estimates of spawning biomass range between 250 and 400 thousand tons. The delimitation of this stock, particularly the location of the northern boundary, has been challenged in recent years and several studies were carried out to assist its revision in the near future (e.g. Anon., 2006; ICES, 2006; Bernal et al., 2007). Off the English Channel and North Sea, sardine is apparently much less abundant than in neighbouring French waters (ICES, 2006) although there is evidence that sardine abundance is increasing in the northern limit of its distribution (Beare et al., 2004).

Sardine populations show large variation in size and age structure across the northeastern Atlantic and Mediterranean waters. Geographic differences in the mean length-at-age often associated with differences in size and age structure, may reflect size-specific migrations between areas (Nøttestad et al., 1999; Villamor et al., 2004) or alternatively, separate growth patterns (c.f. Begg, 2005 and references therein). Over broad spatial scales, growth patterns are often observed to vary with latitude such that larger and faster growing populations occur in more northern areas, in apparent contradiction with general environmental gradients expected to influence growth (Conover, 1992). Growth trends corresponding to a geographical pattern of genotypes (countergradient variation), may have developed as an adaptation to environmental seasonality, enabling populations to survive longer, colder and resource-poor winters at higher latitudes. On the other hand, persistent differences in growth trajectories, often combined with differences in maximum length, maximum age or age distributions may indicate some degree of separation between fish populations within a given life phase and be used to define or corroborate stock structure (Begg and Waldman, 1999).

This study describes spatial and temporal variations in sardine growth across the northeastern Atlantic and Mediterranean waters. Samples collected opportunistically in recent years across the species range are used to explore variations in sardine length-at-age and growth performance at a broad geographic scale. A more detailed description of the variations in sardine growth between areas, decades and seasons is presented for the Iberian - Biscay region, using acoustic survey data collected annually since the mid-1980s and monthly samples from the landings in 2004 and 2005 . The observed broad scale geographic variability in sardine growth is then related to existing knowledge in population structure, migration patterns and latitudinal trends in temperature seasonality and plankton production. The implications of spatial growth differences to the definition and assessment of the AtlantoIberian stock are also discussed. 


\section{Materials and methods}

\subsection{Samples}

Samples collected opportunistically within the remit of various international projects in the period 1999 - 2004 were used to describe the broad-scale variation of sardine mean lengthat-age and growth performance across the northeastern Atlantic and the Mediterranean Sea. Overall, 42 samples of sardine (3827 fish) were collected in the coastal Atlantic waters between the English Channel and Mauritania, off the Atlantic Islands of Azores and Madeira, in the western Mediterranean waters from the Balearic Islands to the Gulf of Lyon and in the Aegean Sea (Table 1, Fig. 1). Most of the samples were collected with pelagic trawls during research surveys, although samples from the English Channel were collected from beach seine landings and those from Azores, Madeira, north Morocco and Mauritania were collected from purse seine landings. In all cases, samples consisted of random collections of individuals from survey hauls or landings; despite the weak size selectivity of purse and beach seine nets some undersampling of the smallest individuals is expected in samples from the commercial fisheries due to the market preference for sardines above $15-16 \mathrm{~cm}$ for fresh consumption and the canning industry and a minimum landing size of $11 \mathrm{~cm}$. Samples were transferred frozen to the laboratory of IPIMAR for routine biological sampling and extraction of otoliths.

Samples collected during spring acoustic surveys in the Atlantic coastal waters from Brittany (France) to the Gibraltar Strait (Gulf of Cadiz, Spain) were used to describe in more detail the spatio-temporal variation of sardine growth within the Iberian - Biscay region (Table 2, Fig. 1). Surveys were carried out in February-April off Portugal and Cadiz, March-April off northern Spain and April-June in French waters, broadly following the latitudinal progression of sardine spawning season (Coombs et al., 2006; Stratoudakis et al., 2007). Length and age data are available from the French waters since 2000 while the northern region of the Iberian Peninsula was sampled since 1986 with gaps in some years. Off Portugal and the Gulf of Cadiz, regular sampling started in 1996 with two surveys covering only Portuguese waters in the mid-1980s. Otoliths were collected from length-stratified samples in the Portuguese (1015 otoliths per half-centimetre in each area, see Fig. 1) and French surveys (2-4 otoliths per half-centimetre in each haul) and from random samples of 40 fish per fishing haul in Spanish surveys. The average number of otoliths collected by year and area for ages 1 to 6 years (used for growth modelling) ranged between 158 and 521 (Table 2).

Monthly or bi-monthly samples of sardine collected within the Iberian waters from the landing harbours were used to study sardine seasonal growth and to explore relationships between growth and biological/environmental variables during recent years (2004-2005). Lengthstratified samples (5-10 fish by half-centimetre) were collected at the main fishing ports of the Cantabrian Sea (including catches from southern French waters), north and south Portugal (Fig. 1). The final number of fish sampled by month and year is variable both within and between areas, ranging between 30 and 250 in the Cantabrian Sea, 100 and 300 in north Portugal and 50 and 150 in south Portugal, with gaps in a few months. The monthly length distribution of catches was not available for some of the areas, preventing to account for the length-stratification of samples on the estimation of length-at-age.

\subsection{Biological sampling}

Total length (cm), sex (female, male) and age were recorded for all sardines sampled. Sex could not be determined in a few juvenile (total length below $10 \mathrm{~cm}$ ) and some large (above $22-23 \mathrm{~cm}$ ) individuals. In samples collected from the market, total weight $(\mathrm{g})$ and macroscopic maturity stage (Pinto and Andreu, 1957) were also recorded. Otoliths (sagittae) were extracted from the fish, cleaned in water and mounted in black polyester plates using a synthetic resin. Otoliths were viewed on standard dissecting microscopes at 20-30x magnification. Age determination of sardine from acoustic surveys or market samples within the Iberian - Biscay region was carried out in national laboratories (IPIMAR for Portugal, IEO for Spain and IFREMER for France) while otoliths from recent opportunistic samples were read by a single experienced reader from IPIMAR. In both cases, age readers followed the 
guidelines of international workshops held within the study period (ICES, 1997; FAO, 2001; Soares et al., 2002). Standard protocols for sardine age determination assume the $1^{\text {st }}$ of January as the average birth-date of the species and consider that a set of one opaque zone, laid down during the fast growing period, and one translucent zone, formed during the slow growing period, correspond to annual growth zone, annulus. Fast growing periods usually coincide with the period of planktonic blooms, which may occur between late-winter (e.g. in the Mediterranean) and early summer (e.g. northern Atlantic areas) whereas slow growing periods take place in the less productive seasons. Age, in years, is thus determined as the number of complete translucent zones. During the first semester of the year, the last translucent zone is considered complete, and hence counted, whereas during the second semester the translucent zone in the otolith edge is considered to be in formation and it is not counted.

The birth-date convention matches the mid-spawning season across the area from western Iberia to Mauritania and in the Mediterranean waters (Abad and Giráldez, 1993; Coombs et al., 2006; Stratoudakis et al., 2007; Ganias et al., in press). On the other hand, a lag of 3-5 months is observed relative to the spawning peak in the northern Atlantic areas (from the English Channel to the Cantabrian Sea). To our knowledge, data on sardine spawning are not available for the Atlantic islands of Azores and Madeira, however, the application of the $1^{\text {st }}$ of January birth-date to these areas may not introduce serious bias since peak spawning off the Canary Islands is also known to occur in winter (Mata et al., 1997).

Absolute age based on annual growth rings has not been validated in most areas of the sardine distribution. However, daily growth studies carried out on sardine recruits from Galician, Cantabrian and northwest Mediterranean waters provide a detailed description of growth during the first year of life, permitting to identify the location of the first true annual translucent ring (Alvarez and Alemany, 1997; Alemany et al., 2006). In addition, the periodicity of otolith growth zones was shown to be annual off northwest Spain, Portugal, west Africa and northwestern Mediterranean, from studies of the monthly evolution of the otolith edge (Jorge and Monteiro, 1980; Álvarez and Porteiro, 1981; Krezptowski, 1983) or length frequency analysis (Pertierra and Morales-Nin, 1989). Annual growth rings were observed in sardine scales within the same areas (Andreu and Plaza, 1962; Bravo de Laguna et al., 1979) and shown also for sardines sampled off the English Channel (Hickling, 1945) and the French Gulf of Biscay (Furnestin, 1943). The annual pattern of alternating translucent and opaque rings formed during winter and spring-summer respectively, further suggests that sardine grows mainly during spring and summer in most areas.

It must be highlighted that the clarity of sardine otoliths declines from north to south in the Atlantic waters and is also poor in the Mediterranean Sea, due to decreasing contrast between opaque and translucent zones and to the appearance of false rings (Pertierra and Morales-Nin, 1989; Soares et al. 2002). In a recent sardine age reading workshop, otoliths from southern Iberia and west Africa with poor readability were shown to decrease the agreement between readers and the precision of mean length-at-age estimates (although bias was not observed). Age determination in the southern areas of the Atlantic and in the Mediterranean waters is further complicated by the broad spawning season; since spawning may extend for several months, the first winter ring forms at variable distances from the otolith nucleus or may be preceded by a clear translucent zone which confounds the identification of the true annual ring (Alemany and Álvarez, 1993; ICES, 1997).

\subsection{Data analyses}

To describe the broad scale spatial variation of sardine growth, recent samples collected across the Atlantic and Mediterranean waters were grouped into areas, roughly according to ICES or FAO Divisions (Table 1). Von Bertalanffy growth curves (see subsection on Growth models) were fitted to length-at-age data by area and used to predict length-at-age 2 and age 4 years. Growth modelling was restricted to areas where the number of length-at-age observations and the range of lengths and ages sampled were sufficient to describe the growth trajectory. Since samples were collected in different periods of the year, age in years of each individual fish was converted to age in decimal years for growth modelling, taking into account the average birth-date in the area and the sampling date. Based on Stratoudakis et 
al. (2007, and references therein), assumed birth-dates were May for the French areas (NFRA, SFRA), March for the northern Spanish waters (ECAN and NGAL) and January for the remaining areas (NPOR, SPOR, CAD, NMOR, MAU and WMED). For the remaining areas, the mean length-at-age 2 or age 4 (whichever was best represented) was calculated.

The study of spatio-temporal variability in sardine growth across the Iberian-Biscay region was based on survey samples pooled into nine areas (Fig. 1 and Table 2): north France, south France, Cantabrian Sea, north Galicia, south Galicia, north Portugal, southwest Portugal, south Portugal and Gulf of Cadiz. These areas are routinely used for estimation of sardine abundance and length structure by acoustic methods (ICES, 2006). Age-length keys (ALKs) were constructed for each area, year and sex using biological samples and subsequently raised to the population using length frequency distributions. The resulting matrices of fish abundance by length class and age in each area, year and sex (population ALKs) were used to calculate the mean and variance of length-at-age using standard formulas for grouped data (Zar, 1996). Estimates of mean length-at-age and variance for combined sexes, areas or periods were based on pooled population ALKs. Differential growth by sex was explored using annual estimates of mean length-at-age across the Iberian-Biscay waters between 2000 and 2005. To compare growth among areas and over time, data were pooled into three periods: 1986 - 1993 containing data for northern Spain (from the Cantabrian Sea to south Galicia), 1996 - 1999 containing data for the Iberian areas and 2000 - 2005 containing data for the whole study area (Iberian - Biscay waters). Growth curves were fitted to the mean lengths-at-age in each period and area using inverse variances as weighting factors to account for the decrease of variance with age (Kimura, 1980).

The seasonal growth of sardine was described using length-at-age data from each individual fish in market samples. The monthly length increments of age 2 individuals were calculated from seasonal growth models fitted separately to data from the Cantabrian Sea, north and south Portugal. Seasonal variations in condition were evaluated by changes in total weight of a given length class in each area. As the monthly mean total weight showed similar temporal variations in the different length classes, data for $20-20.9 \mathrm{~cm}$ fish (the best sampled length classes across areas during the study period) were used, assuming them to be representative of the average condition of the whole population. The percentage of fish spawning was calculated as the \% individuals in pre-spawning and spawning maturity stages. Spearman rank correlation coefficients (Zar, 1996) were used to test the significance of the relationships between the seasonal cycles of biological and environmental variables.

Monthly averages of sea surface temperature (SST) and Chl a in $2004-2005$ were estimated from daily remote sensing data for the fishing areas from which sardine were sampled for seasonal growth analyses (Fig. 1). Chl a estimates were extracted from the $9 \mathrm{~km}$ resolution SeaWiFS (Sea-viewing Wide Field-of-view Sensor) Chl a concentration standard mapped images (L3SMI product, Thomas and Franz, 2005). SST averages were computed from EUMETSAT's Ocean and Sea Ice Satellite Application Facility (O\&SI SAF) "Regional SST" product, for the "CANA" and "GASC" regions. These SST estimates are computed using data from the AVHRR (Advanced Very High Resolution Radiometer) instrument on board the polar orbiting NOAA satellites, and are comparable to the in situ measurements at night (Brisson et al., 2001).

\subsection{Growth models}

Growth was modelled using the Von Bertalanffy (VB) curve with the parameterization proposed by Schnute (1981). Compared with the traditional VB model, this parameterization provides estimators with better statistical properties (close to obeying asymptotic properties and less correlated), ensures faster convergence from departing initial estimates and provides parameters of simple biological interpretation (Schnute, 1981; Ratkowski, 1986). Annual growth is described by the expression (Schnute, 1981):

$L_{t}=I_{i}+\left(I_{j}-I_{i}\right) *\left\{1-\exp \left[-k *\left(t-t_{i}\right)\right]\right\}\left\{\left\{1-\exp \left[-k *\left(t_{j}-t_{i}\right)\right]\right\}\right.$ 
where $\mathrm{k}$ (growth coefficient), $\mathrm{I}_{\mathrm{i}}$ (expected length at age $\mathrm{i}$ ) and $\mathrm{l}_{\mathrm{j}}$ (expected length at age $\mathrm{j}$ ) are model parameters, $t_{i}$ and $t_{j}$ are reference ages, in years, and $L_{t}$ is the expected length at age $t$ (years). The proportion between two successive annual length increments is given by exp(- $k$ ) such that large/small $k$ values indicate a fast/slow declining growth with age (Schnute and Fournier, 1980).

To describe seasonal growth, the annual growth model was modified to include sinusoidal variation in length-at-age as suggested by Quinn and Deriso (1999):

$$
\mathrm{L}_{\mathrm{t}}=\mathrm{I}_{\mathrm{i}}+\left(\mathrm{I}_{\mathrm{j}}-\mathrm{I}_{\mathrm{i}}\right) *\left\{1-\exp \left[-\mathrm{k} *\left(\mathrm{t}-\mathrm{t}_{\mathrm{i}}-\left(\mathrm{F}(\mathrm{t})-\mathrm{F}\left(\mathrm{t}_{\mathrm{i}}\right)\right)\right]\right\} /\left\{1-\exp \left[-\mathrm{k} *\left(\mathrm{t}_{\mathrm{j}}-\mathrm{t}_{\mathrm{i}}-\left(\mathrm{F}\left(\mathrm{t}_{\mathrm{j}}\right)-\mathrm{F}\left(\mathrm{t}_{\mathrm{i}}\right)\right)\right]\right\}\right.\right.
$$

where

$$
F\left(t_{x}\right)=\left(C / 2^{\star} \pi\right)^{\star} \sin \left[2^{\star} \pi\left(t_{x}-t_{s}\right)\right] \text { and } t_{x}=t, t_{i}, t_{j}
$$

$\mathrm{C}$ is a dimensionless non-negative constant expressing the amplitude of the seasonal growth oscillation, $t_{s}$ is the phase shift of the growth oscillation in relation to the start of the year, expressed as a fraction of the year, and $t$ is age in decimal years. For an annual cycle, a phase shift $t_{s}=0$ (or 0 plus any integer) indicates that minimum growth occurs in January and the growing period ranges from April $\left(t_{s}+0.25\right.$ year) to October $\left(t_{s}+0.75\right.$ year) (Quinn and Deriso, 1999). The value of $C$ indicates the magnitude of growth around the yearly time of minimum growth, ranging from zero for continual growth (nonseasonal) to 1 for null growth and to values above 1 for negative growth. No attempt was made to constrain the value of $C$ to avoid negative growth; models with free and constrained $(=1)$ C gave similar estimates of the remaining parameters while the former provided a better fit to the data.

Models were fitted by nonlinear least squares using the Gauss-Newton algorithm and 95\% approximate inference intervals were calculated for growth parameters and expected values of length-at-age (Bates and Watts, 1988). Ages 1-6 years were used to model seasonal and annual growth of sardine from the Iberian-Biscay region. In annual models, ages $t_{i}$ and $t_{j}$ were taken to be 1 and 5 years old (thus, $l_{i}=l_{1}$ and $l_{j}=I_{5}$ ). In seasonal models, reference ages were adjusted to the beginning of April to match the average survey dates and therefore, $\mathrm{t}_{\mathrm{i}}=1.25$ and $t_{j}=5.25$ years. In the study of broad-scale variability of growth, older ages were poorly represented in some areas therefore, growth models were fitted to ages 1-5 years and reference ages were taken to be 2 and 4 years old (thus, $\mathrm{l}_{\mathrm{i}}=\mathrm{l}_{2}$ and $\mathrm{l}_{\mathrm{j}}=\mathrm{l}_{4}$ ). In a few cases, the growth coefficient of the VB model was not significantly different from zero suggesting linear growth across the range of observed ages and a linear regression model was fit to the respective length-at-age data.

To study sardine growth variability within the Iberian - Biscay region, area-based VB curves were compared by likelihood - ratio tests (Kimura, 1980). The hypothesis of separate curves for each pair of areas was set as a base case and tested against a sequence of hypotheses assuming that some of the growth parameters are shared. The first of these hypotheses tested simultaneous equality of the three growth parameters (i.e. whether the curves are coincident and therefore a single growth curve fits best the data). When this hypothesis was rejected, further tests were carried out to evaluate differences between curves in each growth parameter at a time $\left(\mathrm{l}_{\mathrm{i}}, \mathrm{l}_{\mathrm{j}}\right.$ or $\left.\mathrm{k}\right)$. Depending on the most parsimonious model fitting the data, we classified the relationship between two growth curves, 1 and 2, in one of the following categories:

parallel, when $\mathrm{k} 1=\mathrm{k} 2$ and $\left(\left|1_{\mathrm{i}}>\right| 2_{\mathrm{i}}\right.$ and $\left|1_{\mathrm{j}}>\right| 2_{\mathrm{j}}$ or vice-versa);

convergent, when $I 1_{\mathrm{i}} \neq \mid 2_{\mathrm{i}}$ and $I 1_{\mathrm{j}}=\mathrm{I} \mathrm{2}_{\mathrm{j}}$

divergent, when $I 1_{i}=\mid 2_{i}$ and $I 1_{j} \neq \mid 2_{j}$

separate, when either all three parameters were significantly different or when lengths at reference ages were such that growth trajectories crossed (i.e., $\left|1_{i}>\right| 2_{i}$ and $\left|1_{j}<\right| 2_{j}$ or viceversa).

Significance levels were 0.01 in the comparison of sex-specific growth curves and 0.001 in comparison of growth curves for different areas, to account for multiple comparisons. 
Growth patterns obtained from broad-scale samples collected within the northeastern Atlantic and the Mediterranean were compared between areas and contrasted with literature information using the relationship between $\log _{10} \mathrm{~K}$ and $\log _{10} \mathrm{~L}^{\infty}$ (auximetric plot; Cury and Pauly, 2000). For most species, this relationship is linear with a slope of -2 and an intercept which defines an average species-specific growth index, Ф' (for a review see Pauly, 1991). The growth index may be viewed as the theoretical growth coefficient, $k$, for individuals of 1 unit length and be used to compare the growth performance between populations and species. $L \infty$ values were derived for each area from the parameters of the fitted VB models as (Schnute, 1981):

$L \infty=\left\{\mathrm{l}_{\mathrm{i}}-\mathrm{l}_{\mathrm{j}} \exp \left[-\mathrm{k}^{*}\left(\mathrm{t}_{\mathrm{j}}-\mathrm{t}_{\mathrm{i}}\right)\right]\right\} /\left\{1-\exp \left[-\mathrm{k} *\left(\mathrm{t}_{\mathrm{j}}-\mathrm{t}_{\mathrm{i}}\right)\right]\right\}$

80 estimates of $k$ and $L \infty$ were compiled from studies of sardine growth in several periods and areas across the northeastern Atlantic and the Mediterranean Sea (Guerrault, 1980; Monteiro and Jorge, 1982; Krzeptowski, 1983; Morales-Nin and Pertierra, 1990; Alemany and Álvarez, 1993; FAO 2001; Voulgaridou and Stergiou, 2003; and references therein). A linear regression model was fitted to these estimates and used explore the application of the growth index formula to sardine (Pauly, 1991):

$\Phi^{\prime}=\log _{10} k+2 \log _{10} L^{\infty}$

All calculations were carried out with R 2.4.0 (R Development Core Team, 2006).

\section{Results}

\subsection{Sex-specific growth}

Sex-specific growth curves for sardine, based on pooled survey data from the Iberian Biscay region in $2000-2005$, are not coincident $(p=0.004)$ due to significantly larger female $I_{5}$ $(p=0.005)$ as indicated by log - likelihood ratio tests. The most parsimonious growth model provided $\mathrm{I}_{5}( \pm$ S.E.) estimates of $21.4 \pm 0.10 \mathrm{~cm}$ for females and $21.0 \pm 0.10 \mathrm{~cm}$ for males but common estimates of $I_{1}$ and $k\left(14.4 \pm 0.10 \mathrm{~cm}\right.$ and $0.73 \pm 0.041$ year $\left.{ }^{-1}\right)$. These results indicate that male and female sardines have diverging growth trajectories, however differences in expected lengths are small up to age 6, as shown by overlapping $95 \%$ inference intervals (Fig. 2).

\subsection{Broad - scale spatial variation}

Sardine total length in the broad - scale samples ranges between 10.9 and $27.2 \mathrm{~cm}$, corresponding to ages of $0-14$ years (Table 1 ). Off the English Channel, sampled individuals were older than 2 years, showed the oldest age and length among all samples $(27.2 \mathrm{~cm}$ and 14 years) and the largest length-at-age 4 across the Atlantic areas apart from Mauritania (Table 1, Fig. 3). Samples from the northeastern Atlantic suggest a latitudinal decline of mean length-at-age from north France to north Morocco and a sharp increase off Mauritania. Sardines sampled in the western Mediterranean show lower lengths, at ages 2 and 4 years, than those sampled in the Atlantic apart from the Gulf of Cadiz and north Morocco. There is also some indication that sardine length-at-age declines from the western to the eastern Mediterranean (Aegean Sea) while the length of age 2 sardines from the Atlantic islands is similar to that of southern Iberia and western Mediterranean individuals (Fig. 3). Geographical variations are generally smooth but result in substantial differences when distant areas are compared; in fact, at similar ages, sardines from north France are larger than those from north Portugal by ca. $2 \mathrm{~cm}$, and the latter are larger than those from the Gulf of Cadiz, western Mediterranean and north Moroccan by ca. $1 \mathrm{~cm}$. Differences in length-at-age are maximum (ca. $3 \mathrm{~cm}$ ) when sardines sampled off north Morocco or off the western Mediterranean are compared with those from Mauritania.

VB growth curves explained more than $70 \%$ of the variance in length-at-age data from each area. The auximetric plot indicates that growth parameters obtained in this study are generally 
within the range of values reported in earlier studies (Fig. 4). Pairs of $\log _{10} k$ and $\log _{10} L \infty$ are widely scattered around a regression line with slope $2.04(\mathrm{~S} . \mathrm{E} .=0.40)$ and intercept 2.46 (S.E. $=0.54)$ which explains a low (but significant) percentage of total data variance $\left(r^{2}=0.22\right.$, $\mathrm{N}=90, \mathrm{p}<0.05$ ) (Fig. 4). Although the slope estimate provides some support to the growth index formula (Munro and Pauly, 1983) the model shows clearly a poor fit to the main cluster of points. This cluster contains almost exclusively data from the northeastern Atlantic areas (but also 2 points from the southwestern Mediterranean) and suggests that a model with both a steeper slope and a larger intercept would be preferred. In addition, the sparser data from the western and eastern Mediterranean seem to align along a parallel axis raising the hypothesis that two linear regressions with a common slope but different intercepts for the Mediterranean and Atlantic areas would provide a better description of data.

This hypothesis was tested against the hypothesis of a common linear regression model; an indicator variable with levels for Atlantic and Mediterranean areas was added to the common model and the two models were compared by an F-test. The test showed that the model with a common slope of -3.24 (S.E. $=0.40)$ but separate intercepts, $4.13(\mathrm{~S} . \mathrm{E} .=0.54)$ and 3.84 (S.E. $=0.52$ ) for the Atlantic and the Mediterranean areas respectively, provided a better fit to the data $(F=33.9$ on 1 degree of freedom, $p<0.05)$ and improved the percentage of total explained variance to $43 \%$. This result suggests that sardine from the Mediterranean Sea (apart from the southwestern area) and the northeastern Atlantic may represent two groups with separate average growth performances (given by the intercepts of the $\log _{10} \mathrm{k}-\log _{10} \mathrm{~L} \infty$ regression lines) and indicates that the slope of this relationship is steeper than the value (-2) assumed to represent a cluster of stocks from a single species (Pauly, 1991; Cury and Pauly, 2000).

Table 3 presents for each area the values of Munro and Pauly (1983) growth index and of a modified index $(\mathrm{Gl})$ obtained when the species constant $(-2)$ is replaced by the slope from separate $\log _{10} k-\log _{10} L \infty$ regression lines for Atlantic and Mediterranean waters. Although the two indices are positively correlated and suggest that the growth performance of sardine is higher off the northern Atlantic areas (French waters) and poorer in southern Iberia, north Morroco and west Mediterranean waters, they provide a distinct perspective of sardine growth performance off Mauritania; $\Phi$ ' suggests that sardine growth performance off Mauritania and western Mediterranean are comparable while Gl suggests a higher similarity between Mauritania and the northern areas.

\subsection{Spatio-temporal variation within the Iberian-Biscay region}

Sardines between 9.6 - $27.6 \mathrm{~cm}$ total length and 1-13 years were sampled within the Iberian Biscay region since the mid-1980s (Table 2). Maximum length declines from north to south corroborating the trend detected in the broad - scale samples (see previous section). Mean length shows a similar geographical trend but lower mean ages are associated with recruitment areas such as northern Portugal/south Galicia, Gulf of Cadiz and south France. A VB model fitted to annually pooled samples for 2000-2005 across the region showed that sardine grows from $15.3 \mathrm{~cm}($ S.E. $=0.41 \mathrm{~cm})$ at age 1 to $23.0 \mathrm{~cm}(\mathrm{~S} . \mathrm{E} .=0.02 \mathrm{~cm})$ at age 10 . Annual growth increments decline $64 \%$ in each successive age $\left(k=0.44\right.$ year $^{-1}$, S.E. $=0.06$ year ${ }^{-1}$ ) such that individuals attain $90 \%$ of their maximum length at age 4.

VB growth curves fitted significantly to length-at-age data from most areas and periods; the percentage of length variance explained by the models ranged between 68 and $97 \%$ and absolute values of correlations between model parameters did not exceed 0.63 . In two cases, Gulf of Cadiz in 1996 - 1999 and south Galicia in 2000 - 2005, sardine growth was best described by a linear model indicating a constant growth increment across the observed range of ages. Fig. 5 shows the parameters of growth models fitted to sardine samples pooled by area and period and Table 4 summarises the results of log-likelihood ratio tests comparing growth curves. 95\% inference intervals of growth parameters from different periods show considerable overlap in all areas, suggesting that sardine growth did not change significantly across the study period. Overall, growth curves are coincident across the area from north France to north Galicia and between north and southwest Portugal. Furthermore, growth curves from these two broad regions are generally parallel while $l_{1}$ estimates are 
significantly larger in the former region. In the period 1996 - 1999, the growth curve for south Galicia is divergent from those of northern areas and convergent with those from the west Portugal. A similar pattern occurs in recent years, as shown by predicted lengths-at-age from the linear model (Fig. 5) indicating that length-at-age 1 in south Galicia is more typical of northern areas but length-at-age 5 resembles that off the west Portuguese waters. Growth curves from south Portugal and Cadiz show variable relationships with other areas with no clear spatial or temporal patterns. Nevertheless, sardine from south Iberia show significantly larger length-at-age 1 than sardine from west Portugal and significantly lower length-at-age 5 than sardine from north Iberia- Biscay, in most pair-wise comparisons.

Overall, sardine growth across the Iberian - Biscay waters follows the large-scale latitudinal decline detected across the northeastern Atlantic waters. The statistical comparison of growth curves evidenced three patterns of length-at-age across the region (Fig. 6): (i) large lengths across ages, typical of north lberia - Biscay waters; (ii) large lengths at young ages but small lengths at old ages, observed both in south Galicia and south Iberia and (iii) small lengths across all ages, typical of west Portuguese waters. In spite of comparable length-at-age patterns, sardines from south Galicia have generally larger lengths-at-age than those from south Iberian areas.

\subsection{Seasonal growth and relationships with biological and environmental variables}

The seasonal growth of sardine is adequately described by the VB model in the three areas off the Iberian Peninsula (Table 5 ). Parameters $I_{1}, I_{5}$ and $k$ estimated by the seasonal models are broadly in agreement with those estimated by the annual models in corresponding areas, apart from the estimate of $k$ for south Portugal. Sardine length-at-age shows strong seasonal variation in all areas, as indicated by the amplitude parameter, C. This parameter is significantly above 1 in models for all areas (but particularly in the Cantabrian Sea and south Portugal), implying decreasing length in the yearly time of minimum growth (winter). This apparent negative growth suggests bias in the estimation of length-at-age, which may be a consequence of overestimation of age in the early months of the year if the true birth date is later than the assumed birth date. Other factors, such as seasonal changes in the availability of larger fish to the fishery may have affected the estimation of length-at-age. The phase shift parameter, $\mathrm{t}_{\mathrm{s}}$, shows that minimum growth occurs in late autumn-winter and maximum growth occurs six months later, in late spring-summer, being slightly earlier in the year off north Portugal than in the two other areas (Table 5).

Fig. 7 presents the average monthly variation of sardine growth, body condition, spawning activity, SST and Chl $\underline{a}$, in the three areas during 2004-2005. Samples used in this study suggest that sardine condition and spawning activity have comparable seasonality in the three areas. Condition is generally lower during winter, when spawning activity is at a maximum, and increases between spring and summer-autumn with the cessation of spawning. In spite of an overall inverse relationship between condition and spawning, the former remains relatively high during the first part of the spawning season, disrupting the correlation between the two variables (Table 6). SST is maximum during summer and minimum during winter but presents different amplitude and absolute values in each area. In the Cantabrian Sea, SST values are lower in the winter (average of January-March $=12.2^{\circ} \mathrm{C}$ ) and higher in the summer SST (average of July-September $=21.4^{\circ} \mathrm{C}$ ) than in the other two areas. Winter SST in north Portugal is slightly above that in the Cantabrian Sea $\left(13.5^{\circ} \mathrm{C}\right)$ but summer values are $3^{\circ} \mathrm{C}$ below $\left(17.8^{\circ} \mathrm{C}\right)$ while in south Portugal SST is the highest during winter months $\left(15.2^{\circ} \mathrm{C}\right)$ and closer to that in the Cantabrian Sea in the summer $\left(20.4^{\circ} \mathrm{C}\right)$. Chl a shows a spring peak in the Cantabrian Sea and low values during summer, showing a significant inverse correlation with the seasonal cycle of SST. On the other hand, a direct relationship between SST and $\mathrm{Chl} \underline{\mathrm{a}}$ is observed off north Portugal since $\mathrm{Chl}$ a shows higher values in the summer due to seasonal upwelling. In south Portugal, Chl a levels are low across the year.

The monthly growth of sardine in the Cantabrian Sea and south Portugal is positively correlated with SST and weight-at-length and negatively correlated with spawning activity 
indicating that sardine grows in length and improves condition concurrently during the summer period, when temperature reaches the highest annual values and spawning activity is minimal (Table 6). The growing season is earlier in the year off north Portugal and although most of the growth occurs in the end of the spawning season when temperature is still rising, correlations are generally weak. Unlike the other two areas, growth in length precedes the increment of body condition which occurs in late summer as in the other two areas. A lag of 34 months is observed between the peak of primary productivity and maximum annual growth and body condition off the Cantabrian Sea. In north Portugal, growth in length takes place when $\mathrm{Chl}$ a shows low values but condition is positively (although not significantly) correlated with primary production.

\section{Discussion}

All sardine age data analysed in this study were obtained using the same type of calcified structure, preparation method and age reading criteria (e.g. FAO, 2001; Soares et al., 2002). The main assumptions underlying age determination, the $1^{\text {st }}$ of January birth-date and the annual periodicity of otolith growth rings, apply reasonably well across most of the species range. Validation of absolute ages is still a matter of concern but verification of increment periodicity for most populations and corroboration of the first growth ring for a few populations from the study area provide a minimum support to the accuracy of age data (Campana, 2001). Nevertheless, other potential sources of error, such as the implication of several age readers, the use of different sample sources and sampling periods may have affected the accuracy and precision of the present results (Campana, 2001) whereas the quality of age data is certainly lower in areas where otolith interpretation is more difficult, such as off south Iberia, Mauritania and Mediterranean waters.

Broad-scale samples suggest that maximum length and length-at-age of sardine decline across the northeastern Atlantic from the English Channel to north Morocco, show low values in western Mediterranean waters, and are substantially higher off Mauritania. Data compiled from earlier studies support these broad geographic patterns and support the general growth index formula (using a slope of -2) (Fig. 4). However, the auximetric plot also indicates that a linear model with a steeper slope and assuming different average growth performances for Atlantic and Mediterranean populations provide a significantly better description of sardine growth parameters. These results suggest that the relationship proposed by Pauly (1979) may vary below the species level, possibly separating groups of populations with larger genetic distance. In fact, sardines distributed in the Atlantic and in the Mediterranean Sea are reproductively isolated, as shown by recent studies of allozyme frequencies (Ramón and Castro, 1997) and mitochondrial DNA markers (Atarhouch et al., 2007) and mixing between populations from the two regions is limited, as indicated by significant differences in meristic (Andreu, 1969) and morphometric characters (Silva, 2003).

The auximetric plot suggests that sardine from Mediterranean areas have a lower average growth performance than sardine from most Atlantic areas. Apart from a lower growth, sardines from the Mediterranean Sea also show lower fecundity and spawning frequency than those from the Atlantic (Ganias et al. 2003, 2004). Lower values for several life history properties and lower abundance of Mediterranean sardine populations may thus be due to the pronounced oligotrophy of this Sea (Stergiou et al., 1997) in comparison to the Atlantic waters. Samples collected off north Morocco and the Gulf of Cadiz (this study) and southwestern Mediterranean (Alemany and Álvarez, 1993) are exceptions to the general growth patterns and may represent transition areas. In fact, some mixing possibly occurs between Atlantic and Mediterranean populations around the Gibraltar Straight, as suggested by the southeastern transport of ichthyoplankton along the Gulf of Cadiz shelf (Rubín et al., 1999). It is also plausible that the boundary between populations from the two seas changes over time since the genetic break has been associated with the Almeria-Oran front in the southwest Mediterranean (Alborán Sea) and this front changes its location closer to the Gibraltar Straight in some years (Atarhouch et al., 2007). 
Sardine populations are genetically homogeneous across northeastern Atlantic from the English Channel to north Morocco (Kasapidis et al., 2004) although spatial differences in morphometric characters (Silva, 2003) and length of first maturity (Silva et al., 2006) suggest some degree of spatial population structuring. Differences in sardine growth patterns between some of the areas may be explained by size- and age-related migrations. This is the case of the English Channel where the absence of young sardines and the greater length of older individuals are consistent with a gradual immigration of the largest individuals from neighbouring recruitment areas in the Bay of Biscay. This hypothesis has been suggested by Furnestin (1943) to explain the predominance of juvenile sardines in the southern part of the Gulf of Biscay, the mixture of young and old fish in the central area and the exclusive presence of large $(>18 \mathrm{~cm})$ and old sardines (mostly 4-5 years) in the English Channel (Hickling, 1945). Size-specific migrations of sardines recruited off the northwest Iberian areas may be responsible for the predominance of large and old sardines off the Cantabrian Sea (Carrera and Porteiro, 2003) and explain the apparently larger growth in this area as shown by our results. This hypothesis has received some corroboration in recent years since strong year-classes originating in the north of Portugal were observed to expand to north Galicia and west Cantabria in the following years (ICES, 2006).

However, differences in sardine length-at-age between recruitment areas such as south Biscay, north Portugal and the Gulf of Cadiz-north Morocco cannot be explained by migration. Instead, these differences suggest a latitudinal gradient in growth across the northeastern Atlantic, as observed for several temperate fish species, including clupeoids (Conover and Present, 1990; Lapolla, 2001). Latitudinal growth trends may have a genetic basis (countergradient growth variation; Conover and Present, 1990) as a consequence of selection pressures related to temperature seasonality and winter survival (Conover, 1992); increased juvenile growth enables populations to sustain longer, colder and often resource-poorer winters at higher latitudes and large body size increases the ability to store energy to reproduce in the beginning of the next growing season. Although countergradient variation cannot be proved from this study, growth differences between sardine populations in different latitudes are consistent with latitudinal gradients of temperature cycles (Coombs et al., 2006). Higher growth during the first year and larger lengths-at-age are observed in the Gulf of Biscay, where seasonal temperature gradients are steeper with temperature falling below 12 ${ }^{\circ} \mathrm{C}$ in winter but reaching high values $\left(19-20^{\circ} \mathrm{C}\right.$ ) during the short summer season (Coombs et al., 2006). Lower sardine growth occurs off west Iberia and north Morocco, where minimum winter temperatures are around $14-15^{\circ} \mathrm{C}$ but summer temperatures do not increase above 20 $21^{\circ} \mathrm{C}$ due to the influence of seasonal upwelling. Furthermore, the latitudinal decline in the duration of the spawning season and the shift from winter to summer of sardine populations across the northeastern Atlantic (Coombs et al., 2006; Stratoudakis et al., 2007) are possibly additional adaptations to temperature seasonality in order to match the preferred SST range for spawning.

Geographic variations in sardine growth across the northwest African waters are well documented (see FAO, 2001 and references therein). The mean length-at-age of sardine increases from north Morocco to Sahara and Mauritania and there is a trend towards lower $\mathrm{L}^{\infty}$-higher $\mathrm{k}$ in the northern part of the region (north of $26^{\circ}-28^{\circ} \mathrm{N}$ ).. Sardine from the northern, (Morocco) and southern (Sahara) areas are considered two different populations separated around the $28^{\circ} \mathrm{N}$ parallel, based on information on body morphology, seasonal migrations, maturity and growth rates (FAO, 2001). Recent studies showed a genetic discontinuity around $30^{\circ} \mathrm{N}$ (Agadir) by allozymes (Chlaida et al., 2005) and DNA (Atarhouch et al., 2007) indicating that Moroccan and Saharan populations are reproductively isolated. The significantly higher growth of sardine off Sahara and Mauritania is possibly due to the combination of high prevailing temperature and productivity (Coombs et al., 2006) and may also represent an adaptation to temperature seasonality. The high summer temperatures (reaching $25-26^{\circ}$ ) may prevent growth and force the growing period to months of comparatively lower temperatures (although still close to the peak summer temperatures of more northerly areas) when upwelling is more intense and therefore plankton production is higher. In fact, an earlier study indicates that sardine feeding intensity and growth are higher from March to June in west Saharan waters, when spawning activity is declining and temperature has not yet reached the peak summer values (Krezptowski, 1983). 
Sardine growth showed marked seasonality in the northern, western and southern areas of the Iberian Peninsula. As other small pelagic fish (Cubillos et al., 2001), sardine from the Iberian areas grows and improves condition outside the main spawning season, when the allocation of energetic resources to gonad development ceases and temperature and food availability are increasing or close to the annual peak. Seasonal growth occurred mainly in summer in the Cantabrian Sea and south Portugal but slightly earlier in the year (spring) off northern Portugal. The reason for this difference is not clear from the data but may be related to the predominance of younger or older individuals in each area, with slightly different growing periods. As other species (William and Bedford, 1974) sardine may delay the main growing period as they grow older and it is plausible that both spring and summer are important growing seasons in the three areas. Association of sardine seasonal growth in the Iberian waters with food availability/quality is complicated by the lack of comparative studies of plankton abundance and sardine feeding at this temporal and spatial scale. Overall, spring growth is consistent with higher feeding intensity in both the north and the south Portuguese waters (Garrido et al., 2006) while both spring and summer growth are in agreement with the periods of higher plankton production off the western Iberian waters due to seasonal upwelling (which extends to the western part of south Iberia) (Cunha, 2001; Moita, 2001).

In spite of the above indications that latitudinal gradients in temperature seasonality, productivity and size-related migrations are important in determining spatial variation in sardine length-at-age, other processes, such as density-dependence and size-selective mortality (Sinclair et al., 2002), may generate geographical differences on the apparent growth trajectory. Size-selective mortality may result from fishing gear and/or fishermen selectivity and cause evolutionary change in growth through persistent removal of the larger individuals from populations (Law, 2000). Although both mechanisms have mainly been associated with temporal changes in life-history traits, they may act on a local scale (Rose et al., 2001). Swain et al. (2003) provide an example that temperature, density dependent effects and size-selective mortality may have a variable influence on the length-at-age of neighbour fish stocks depending on their abundance and exploitation levels. In the case of sardine, both overall abundance and catch levels vary extensively across the study area (FAO, 2004; ICES, 2006) suggesting that influences of population density and fishing mortality on growth patterns warrant further investigation.

Overall, sardine growth evidences large spatial variability that needs to be taken into account for stock assessment and stock structure analyses. Our results show persistent differences in length-at-age among the northern, western and southern areas of the Atlanto-lberian stock, with similar differences anticipated in weight and maturity-at-age. Weight-at-age is expected to vary directly with length-at-age, while maturity-at-age may show a more complex spatial pattern since it also depends on the length at first maturity. Such differences support the current procedure of area-stratification used in biological sampling and calculation of catch, weight and maturity-at-age for assessment purposes (e.g. ICES, 2006), but also suggest that fewer areas may be considered within the stock area. The discontinuity in growth off the northwestern tip of Iberia (Cape Finisterra) is consistent with a size-related north/easterly migration from western recruitment areas and supports the hypothesis that sardine from west and north lberia belong to the same stock. However, the extent of such migration is unknown and the larger mean length at age in northern Iberia may also result from south/westerly movements from the Bay of Biscay recruitment area, where growth is significantly higher than western Iberia. The discontinuity in growth at the southwestern tip of Iberia (Cape St. Vincent) may either indicate populations with limited mixing or a similar size-related emigration from the recruitment area in the inner Gulf of Cadiz where growth is significantly lower than western Iberia. However, the implications of growth differences in sardine stock structure analyses should be considered concurrently with the other phenotypic and genetic evidence from the area. 


\section{Acknowledgements}

This study was developed within the framework of the EU Project SARDYN (Contract Q5RS2002-000818). We thank Khallahi Ould Mohamed Fall (IMROP Mauritania), Jean-Louis Bigot (IFREMER Sète), Nick C. Halliday and the crew of the MBA/PML RVs "Sarsia" and "Plymouth Quest" (MBA, England), Dalila Carvalho (DRPM, Madeira, Portugal), Angela Canha (DOP, Azores, Portugal), and Malika Chlaida (INRH Morocco) for collaboration in the collection of samples (as part of SARDYN and the EU Study PELASSES 080/99), E. Soares, A. Morais, E. Peleteiro (IEO), I. Rico and E. Duhamel for assistance in the laboratory and age reading and P. Beillois for the compilation of French surveys data. We are also grateful to A. Jorge for reading otoliths from samples collected across the whole species range. The collection of regular biological samples from the fisheries was supported by sampling programs of IPIMAR, IEO, and AZTI Foundation integrated in the EU Data Collection Regulation.

\section{References}

Abad, R., Giraldéz, A., 1993. Reproducción, factor de condición y talla de primera madurez de la sardina, Sardina pilchardus, (Walb.), del litoral de Málaga, mar de Alborán (1989 a 1992). Bol. Inst. Esp. Ocean., 8: 145-155.

Alemany, F., Álvarez, F., 1993. Growth differences among sardine (Sardina pilchardus Walb.) populations in western Mediterranean. Sci. Mar., 57, $229-234$.

Alemany, F., Álvarez, I., García, A., Cortés, D., Ramírez, T., Quintanilla, J., Álvarez, F., Rodríguez, J. M. 2006. Postflexion larvae and juvenile daily growth patterns of the Alborán Sea sardine (Sardina pilchardus Walb.): influence of wind. Sci. Mar., 70S2, 93 - 104.

Álvarez, F., Alemany, F., 1997. Birthdate analysis and its application to the study of AtlantoIberian sardine Sardina pilchardus recruitment. Fish. Bull., 95, 187-1194.

Álvarez, F., Porteiro, C., 1981. Growth studies of Sardina pilchardus (Walb.) in Galician waters (N.W. Spain). ICES CM 1981/H:29.

Andreu, B., 1969. Las branquispinhas en la caracterización de las poblaciones de Sardina pilchardus (Walb.). Inv. Pesq., 33, 1-607.

Andreu, B., Plaza, M. L. F., 1962. Estudio de la edad y crecimiento de la sardine (Sardina pilchardus Walb.) del NW de España. Inv. Pesq., 21, 49 - 95.

Anon, 2006. Sardine dynamics and stock structure in the North-eastern Atlantic. Final Report. DGXIV Fisheries, European Comission, Brussel. Q5RS/2002/000818 - available from yorgos@pimar.pt.

Atarhouch, T., Rami, M., Naciri, M., Dakkak, A., 2007. Genetic population structure of sardine (Sardina pilchardus) off Morocco detected with intron polymorphism (EPICPCR). Mar. Biol., 3, $521-528$.

Bates, D. M., Watts, D. G., 1988. Nonlinear Regression Analysis and its Applications. John Wiley \& Sons, New York.

Beare, D., Burns, F., Peach, K., Portilla, E., Greig, T., Mckenzie, E., Reid, D., 2004. An increase in the abundance of anchovies and sardines in the north-western North Sea since 1995. Glob. Ch. Biol., 10, 1-5.

Begg, G. A., 2005. Life history parameters. In: Cadrin, S. X., Friedland, K. D., Waldman, J. R. (Ed.), Stock Identification Methods, Applications in Fishery Science, Academic Press, San Diego, pp. 119-150.

Begg, G. A., Waldman, J. R., 1999. An holistic approach to fish stock identification. Fish. Res., 43, 35-44.

Bernal, M., Stratoudakis, Y., Coombs, S., Angelico, M.M., Lago de Lanzós, A., Porteiro, C., Sagarminaga, Y., Santos, M., Uriarte, A., Cunha, E., Valdés, L., Borchers, D., 2007. Sardine spawning off the European Atlantic coast: Characterization of spatio-temporal variability in spawning habitat. Prog. Oceanog., 74, $210-227$.

Beverton, R. J. H., 1992. Patterns of reproductive strategy parameters in some marine teleost fishes. J. Fish Biol., 41(B), 137-160. 
Bravo de Laguna, J., Fernandez, M. A. R., Goñi, R., Delgado, A., 1979. Growth studies of Sardina pilchardus (Walb.), done by direct methods of scalimetry, off West Africa. ICES CM 1979/H:53.

Brisson, A., Eastwood, S., LeBorgne, P., Marsouin, A., 2001. O\&SI SAF sea surface temperatures: pre-operational results. Proceedings of the 2001 EUMETSAT Meteorological Data Users' Conference, Antalaya, Turkey, 1-5 October.

Campana, S. E., 2001. Accuracy, precision and quality control in age determination, including a review of the use and abuse of age validation methods. J. Fish Biol., 59, $197-242$.

Carrera, P., Porteiro, C., 2003. Stock dynamic of the Iberian sardine (Sardina pilchardus, W.) and its implication on the fishery off Galicia (NW Spain). Sci. Mar., 67 (1), 245-258.

Chlaida, M., Kifani, S., Lenfant, P., Ouragh, L., 2005. First approach for the identification of sardine populations Sardina pilchardus (Walbaum 1792) in the Morocan Atlantic by allozymes. Mar. Biol., 2, $169-175$.

Conover, D. O., 1992. Seasonality and the scheduling of life history at different latitudes. J. Fish Biol., 41 (B), 161-178.

Conover, D. O., Present, T. M. C., 1990. Countergradient variation in growth rate: compensation for length of the growing season among Atlantic silversides from different latitudes. Oecol., 83, 316-324.

Coombs, S. H., Smyth, T. J., Conway, D. V. P., Halliday, N. C., Bernal, M., Stratoudakis, Y., Álvarez, P., 2006. Spawning season and temperature relationships for sardine (Sardina pilchardus) in the eastern North Atlantic. J. Mar. Biol. Ass. U.K., 86, 1245-1252.

Cubillos, L. A., Arcos, D. F., Bucarey, D. A., Canales, M. T., 2001. Seasonal growth of small pelagic fish off Talcahuano, Chile $\left(37^{\circ} \mathrm{S}, 73^{\circ} \mathrm{W}\right)$ : a consequence of their reproductive strategy to seasonal upwelling. Aquat. Living Resour., 14, $115-124$.

Cunha, M. E., 2001. Physical control of biological processes in a coastal upwelling system: comparison of the effects of coastal topography, river run-off and physical oceanography in the northern and southern parts of Portuguese coastal waters. PhD Thesis, University of Lisbon, Lisbon.

Cury, P., Pauly, D. 2000. Patterns and propensities in reproduction and growth of marine fishes. Ecol. Res., 15, $101-106$.

FAO, 2001. Sardine otolith workshop. FAO Fish. Rep., 685, 49pp.

FAO, 2004. Report of the FAO Working Group on the Assessment of Small Pelagic Fish off Northwest Africa. FAO Fish. Rep., 762.

Furnestin, J. 1943. Contribution à l'étude biologique de la sardine atlantique (Sardina pilchardus Walbaum). Rev. Trav. Off. Sci. Tech. Pêch. Mar., 13, 211-340.

Furnestin, J. , Furnestin, M.-L., 1970. La sardine marocaine et sa pêche. Migrations trophiques et génétiques en relation avec l' hydrologie et le plancton. Rapp. P.-v. Réun. Cons. Perm. int. Explor. Mer, 159, 165-175.

Ganias, K., Somarakis, S., Machias, A., Theodorou, A., 2003. Evaluation of spawning frequency in a Mediterranean sardine population. Mar. Biol., 142, 1169-1179

Ganias, K., Somarakis, S., Machias, A., Theodorou, A., 2004. Pattern of oocyte development and batch fecundity in the Mediterranean sardine. Fish. Res., 67, $13-23$.

Ganias, K., Somarakis, S., Koutsikopoulos, C., Machias, A. in press. Factors affecting the spawning period of sardine in two highly oligotrophic Seas. Mar. Biol., 4, 1559 - 1569.

Garrido, S., Cunha, M. E., Oliveira, P. B., van der Lingen, C. D. 2006 Diet composition and feeding behaviour of Iberian sardine (Sardina pilchardus). ICES CM 2006/ F:17.

GFCM, 2006. Report of the eighth session of the sub-committee on stock assessment (SCSA). GFCM:SAC9/2006/Inf.8, ftp://ftp.fao.org/fi/DOCUMENT/gfcm/sac9/inf8e.pdf.

Guerrault, D., 1980. La croissance lineaire de la sardine du Golfe de Gascogne - ses variations a long terme. ICES CM 1980/H:40.

Hickling, C. F., 1945. The seasonal cycle in the Cornish pilchard, Sardina pilchardus Walbaum. J. Mar. Biol. Ass. UK, 26, 115-138.

ICES, 1997. Report of the Workshop on Sardine Otolith Age Reading. ICES CM 1997/H:7.

ICES, 2006. Report to the Working Group on the assessment of Mackerel, Horse Mackerel, Sardine, and Anchovy. ICES Document CM 2006/ACFM:36.

Jorge, I., Monteiro, C. 1980. Preliminary results on the age and growth of sardine pilchardus (Walb.) in sub-area IXa. ICES Document CM 1980/H:38.

Kasapidis, P. Planes, S., Laurent, V., Quinta, R., Teia, A., Lenfant, P., Darivianakis, S., Terzoglou, T., Kotoulas, G., and Magoulas, A. 2004. Stock discrimination and temporal and spatial genetic variation of sardine (Sardina pilchardus) in northeastern Atlantic, with a 
combined analysis of nuclear (microsatellites and allozymes) and mitochondrial DNA markers. ICES CM 2004/Q:21.

Kimura, D. K., 1980. Likelihood methods for the Von Bertalanffy growth curve. Fish. Bull., 77, 765-776.

Krzeptowski, M., 1983. Biological characteristics of the sardine (Sardina pilchardus Walb.) off West Sahara. Acta Ichthyol. Pisc., 13, 13-37.

Lapolla, A. E., 2001. Bay anchovy Anchoa mitchilli in Narragansett Bay, Rhode Island. I. Population structure, growth and mortality. Mar. Ecol. Prog. Ser., 217, 93-102.

Law, R., 2000. Fishing, selection, and phenotypic evolution. ICES J. Mar. Sci., 57, $659-668$.

Mata, M. M., Nespereira, J. M. L., Pajuelo, J. M. G., Aguilera, R. S., 1997. Periodo reproductor y madurez sexual de la sardina Sardina pilchardus (Walbaum, 1792) en aguas de Gran Canaria (islas Canarias). Bol. Inst. Esp. Ocean., 13: 47-55.

Moita, M. T., 2001. Estrutura, variabilidade e dinâmica do fitoplâncton na costa de Portugal continental. PhD Thesis, University of Lisbon, Lisbon.

Monteiro, C., Jorge, I.M., 1982. Age and growth of Sardina pilchardus (Walb.) from the Portuguese coast (ICES Div. IXa). ICES C.M. 1982/H:19.

Morales-Nin, B., Pertierra, J. P., 1990. Growth rates of the anchovy Engraulis encrasicolus and the sardine Sardina pilchardus in the Northwestern Mediterranean Sea. Mar. Biol., 107, $349-356$.

Munro, J. L., Pauly, D., 1983. A simple method for comparing the growth of fish and invertebrates. Fishbyte, 1, 5-6.

Nøttestad, L., Giske, J., Holst, J. C., Huse,G., 1999. A length-based hypothesis for feeding migrations in pelagic fish. Can. J. Fish. Aquat. Sci., 56(S1), 26-34.

Quinn, T. J., Deriso, R. B., 1999. Quatitative fish dynamics. Oxford University Press, New York.

Pauly, D., 1979. Gill size and temperature as governing factors in fish growth: a generalization of the Von Bertalanffy's growth formula. Ber. Inst. Meereskunde, Kiel Univ., 63, XV, $156 \mathrm{p}$.

Pauly, D., 1991. Growth performance in fishes: rigorous description of patterns as a basis for understanding causal meachanisms. Aquabyte, 4,3-6.

Parrish, R. H., Serra, R., Grant, W. S., 1989. The monotypic sardines, Sardina and Sardinops: their taxonomy, distribution, stock structure, and zoogeography. Can. J. Fish. Aquat. Sci., 46, 2019-2036.

Pertierra, J. P., Morales-Nin, B. 1989. Sardine growth in the Catalan Sea (NW Mediterranean) determned by means of otolith interpretation and length frequency data. Sci. Mar., 53: 821 826.

Pinto, J. S., Andreu, B., 1957. Echelle pour la caractérisation des phases evolutives de l'ovaire de sardine (Sardina pilchardus, Walb.) en rapport avec l'histophisiologie de la gonade. Proc. Tech. Pap. Gen. Fish. Counc. Med., 46, 393-411.

Ramon, M. M., Castro, J. A., 1997. Genetci variation in natural stocks of sardine pilchardus from the western Mediterranean Sea. Heredity, 78, 520 - 528.

Ratkowski, D. A., 1986. Statistical properties of alternative parameterizations of the Von Bertalanffy growth curve. Can. J. Fish. Aquat. Sci, 43, $742-747$.

R Development Core Team, 2006. R: a language and environment for statistical computing. $R$ Foundation for Statistical Computing, Vienna, Austria, ISBN 3-900051-07-0, URL http://www.R-project.org.

Rose, K. A., Cowan Jr., J. H., Winemiller, K. O., Myers, R. A., Hillborn, R., 2001. Compensatory density dependence in fish populations: importance, controversy, understanding and prognosis. Fish and Fisheries, 2: 293-327.

Rubín, J.P., Cano, N., Prieto, L., García, C.M., Ruiz, J., Echevarría, F., Corzo, A., Gálvez, J. A.., Lozano, F., Alonso-Santos, J.C., Escanéz, J., Juárez, A., Zabala, L., Hernández, F., García-Lafuente, J., Vargas, M. 1999. La estructura del ecosistema pelágico en relación con las condiciones oceanográficas y topográficas en el Golfo de Cádiz, estrecho de Gibraltar y Mar de Alborán (sector noroeste) em Julio de 1995. Inf. Téc. Inst. Esp. Ocean., 175, 73 pp.

Schnute, 1981. A versatile growth model with statistically stable parameters.

Can. J. Fish. Aquat. Sci., 38, 1128-1140.

Schnute, J., Fournier, D., 1980. A new approach to length frequency analysis: growth structure. Can. J. Fish. Aquat. Sci., 37, 1337-1351.

Silva, A. 2003. Morphometric variation among sardine (Sardina pilchardus) populations from the northeastern Atlantic and the western Mediterranean. ICES J. Mar. Sci., 60, 1352-1360. 
Silva A, Santos MB, Caneco B, Pestana G, Porteiro C, Carrera P, Stratoudakis Y, 2006. Temporal and geographic variability of sardine maturity at length in the north-eastern Atlantic and the western Mediterranean. ICES J. Mar. Sci., 63, $663-676$.

Sinclair, A. F., Swain, D. P., Hanson, J. M., 2002. Disentangling the effects of size-selective mortality, density, and temperature on length-at-age. Can. J. Fish. Aquat. Sci., 59: $372-382$.

Soares, E., Morais, A., Silva, A., Carrera, P., Jorge, A., Rico, I., Peleteiro, Q., Evano, H., 2002. Report of the Workshop on Sardine Otolith Age Reading (Lisbon, 28 January -1 February, 2002). Rel. Cient. Téc. Inst. Invest. Pescas Mar, Série digital (http://ipimariniap.ipimar.pt), 14.

Stergiou, K. I., Christou, E. D., Georgopoulos, D., Zenetos, A., Souvermezoglou, C. 1997. The Hellenic Seas: physics, chemistry, biology and fisheries. Oceanography and Marine Biology: An Annual Review, 35, 415-538.

Stratoudakis, Y., Coombs, S., Lago de Lanzós, A., Halliday, N., Costas, G., Caneco, B., Franco, C., Conway, D., Santos, M. B., Silva, A., Bernal, M. 2007. Sardine (Sardina pilchardus) spawning seasonality in European waters of the northeast Atlantic. Mar. Biol., 152, $201-212$.

Swain, D. P., Sinclair, A. F., Castonguay, M., Chouinard, K. F., Drinkwater, L. P., Fanning, L. P., Clarck, D. S. 2003. Density-versus temperature-dependent growth of Atlantic cod (Gadus morhua) in the Gulf of St. Lawrence and on the Scotian Shelf. Fish. Res., 59, 327 - 341.

Thomas, D. and Franz, B., 2005. Overview of SeaWiFS Data Processing and Distribution, http://oceancolor.gsfc.nasa.gov/DOCS/SW_proc.html.

Villamor, B., Abaunza, P., Fariña, A. C., 2004. Growth variability of mackerel (Scomber scombrus) off north and northwest Spain and a comparative review of the growth patterns in the northeast Atlantic. Fish. Res., 69, 107 - 121.

Voulgaridou, P., Stergiou, K. I., 2003. Trends in various biological parameters of the European sardine, Sardina pilchardus (Walbaum, 1792), in the eastern Mediterranean Sea. Sci. Mar., 67(S1), $269-280$.

Williams, T., Bedford, B. C., 1974. The use of otoliths for age determination. In: Bagenal, T. B. (Ed.), The proceedings of an international symposium on the ageing of fish, Unwin Brothers, England, pp. $114-123$.

Zar, J. H., 1996. Biostatistical analysis. Prentice Hall, New Jersey. 


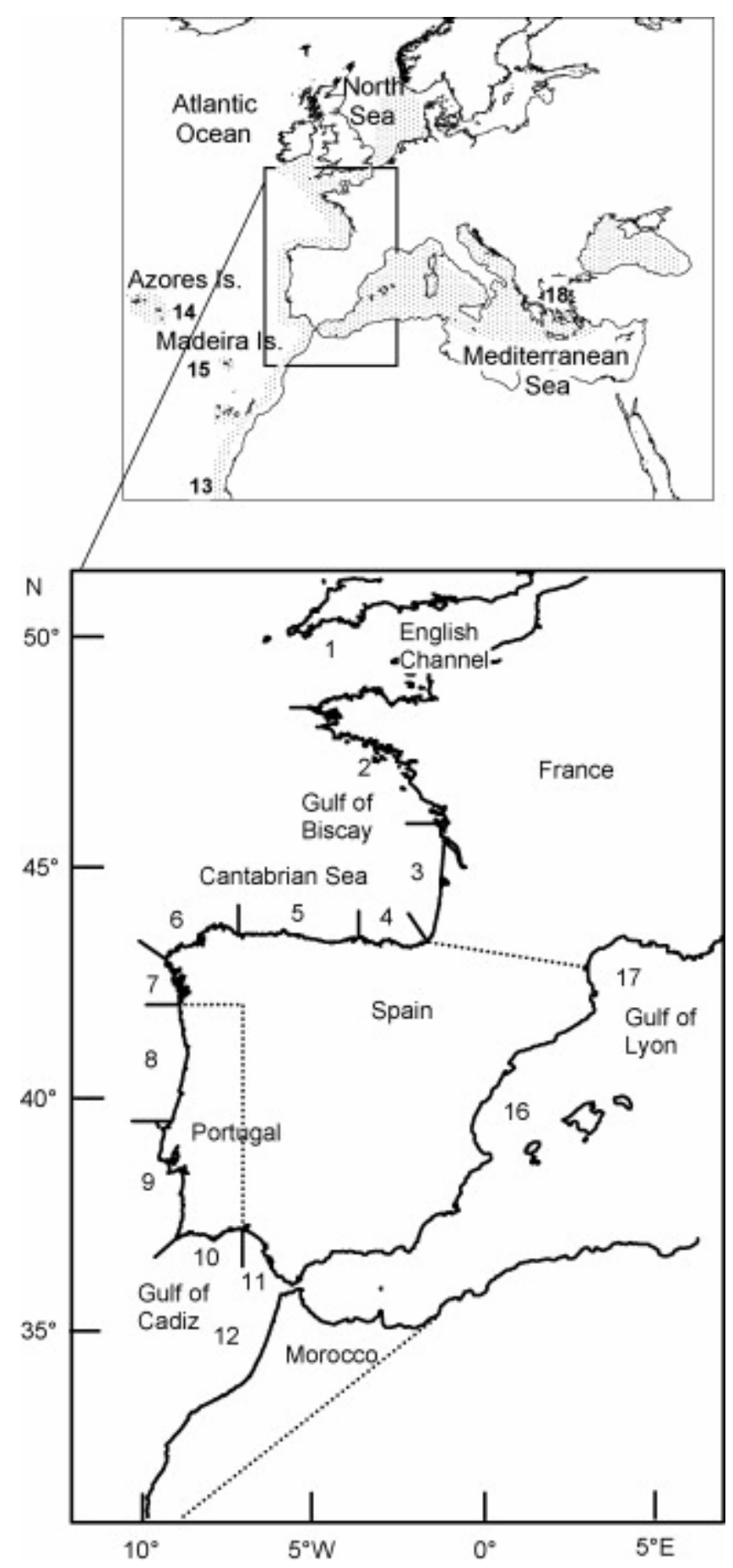

Fig. 1. Map of the study area showing regions considered when pooling data for the analyses of growth. 1 North Sea, 2 North France, 3 South France, 4 East Cantabria, 5 West Cantabria, 6 North Galicia, 7 South Galicia, 8 North Portugal, 9 Southwest Portugal, 10, South Portugal, 11 Gulf of Cadiz, 12 North Morocco, 13 Mauritania, 14 Azores Is., 15 Madeira Is., 16 Western Mediterranean, 17 Gulf of Lyon, 18 Aegean Sea. 


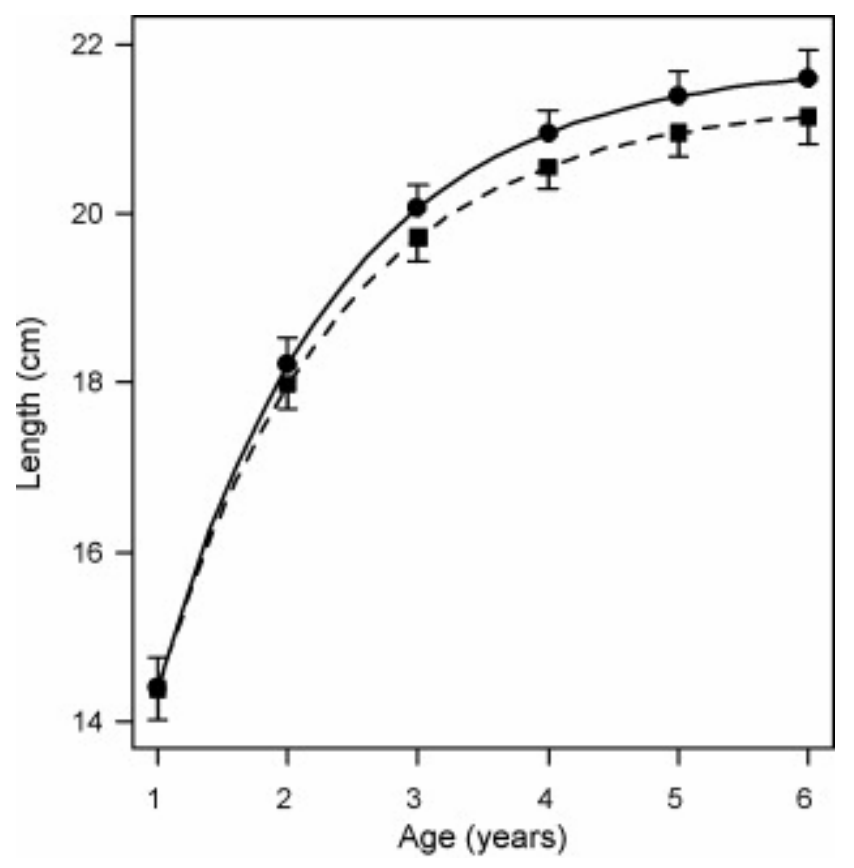

Fig. 2. Average growth curves for female (solid line) and male sardine (dashed line) based on survey data collected across the Iberian - Biscay area in 2000 - 2005. Bars represent $95 \%$ asymptotic inference intervals for length-at-age.

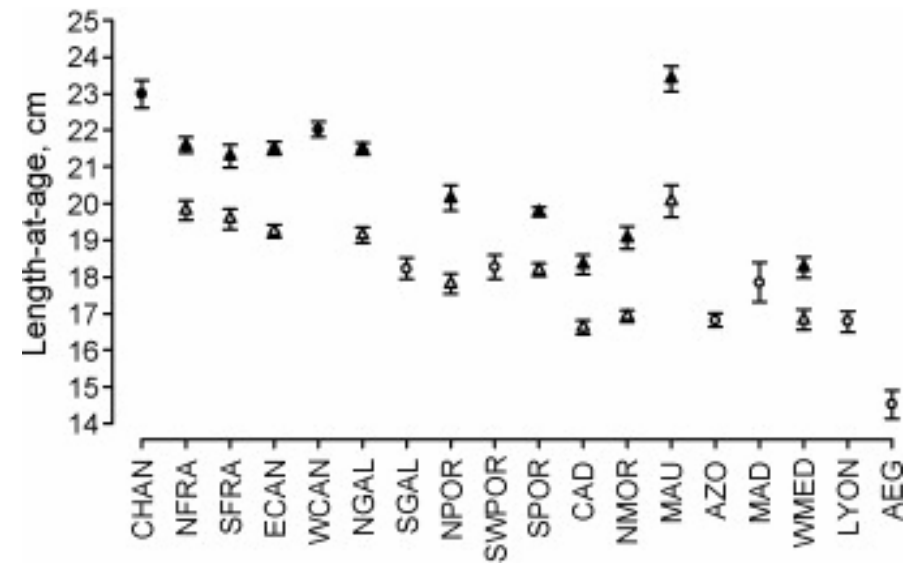

Fig. 3. Mean lengths observed (circles) or predicted by VB models (triangles) for age 2 (open symbols) and age 4 (filled symbols) sardine in each area, using recent samples collected across the northeastern Atlantic and Mediterranean Sea. Bars represent two standard errors of the mean. 


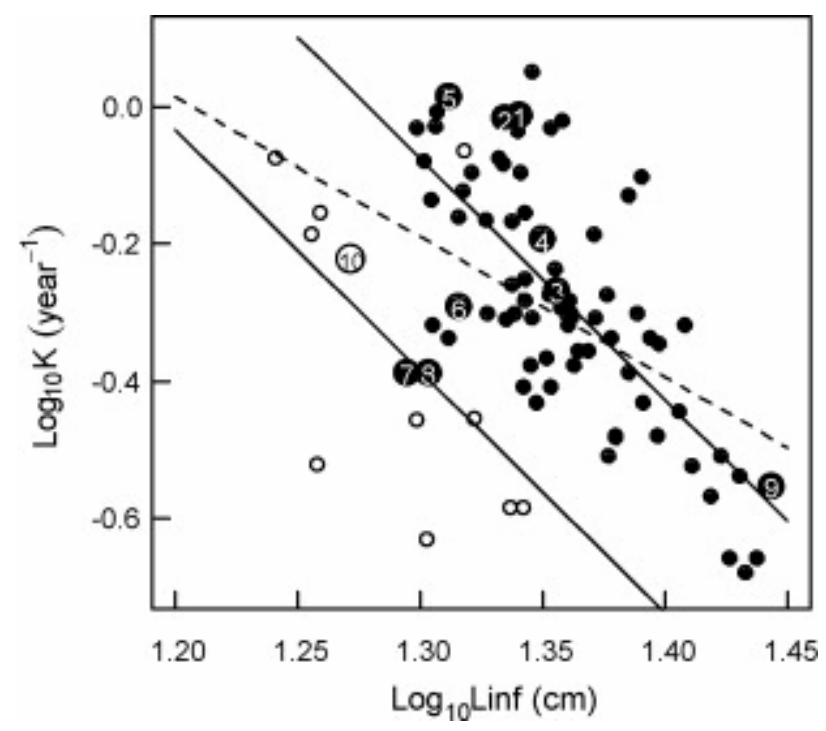

Fig. 4. Auximetric plot of sardine growth parameters, $L^{\infty}$ and $K$, using data compiled from earlier studies within the eastern and western Mediterranean (white circles) and the northeastern Atlantic waters (black circles) (see text for references). Numbers represent parameters obtained in this study for North France (1), South France (2), East Cantabria (3) North Galicia (4), North Portugal (5), South Portugal (6), Gulf of Cadiz (7), North Morocco (8), Mauritania (9) and west Mediterranean (10). Solid lines correspond to the linear regression model assuming separate intercepts for Atlantic and Mediterranean areas and the dashed line represents the common regression model.

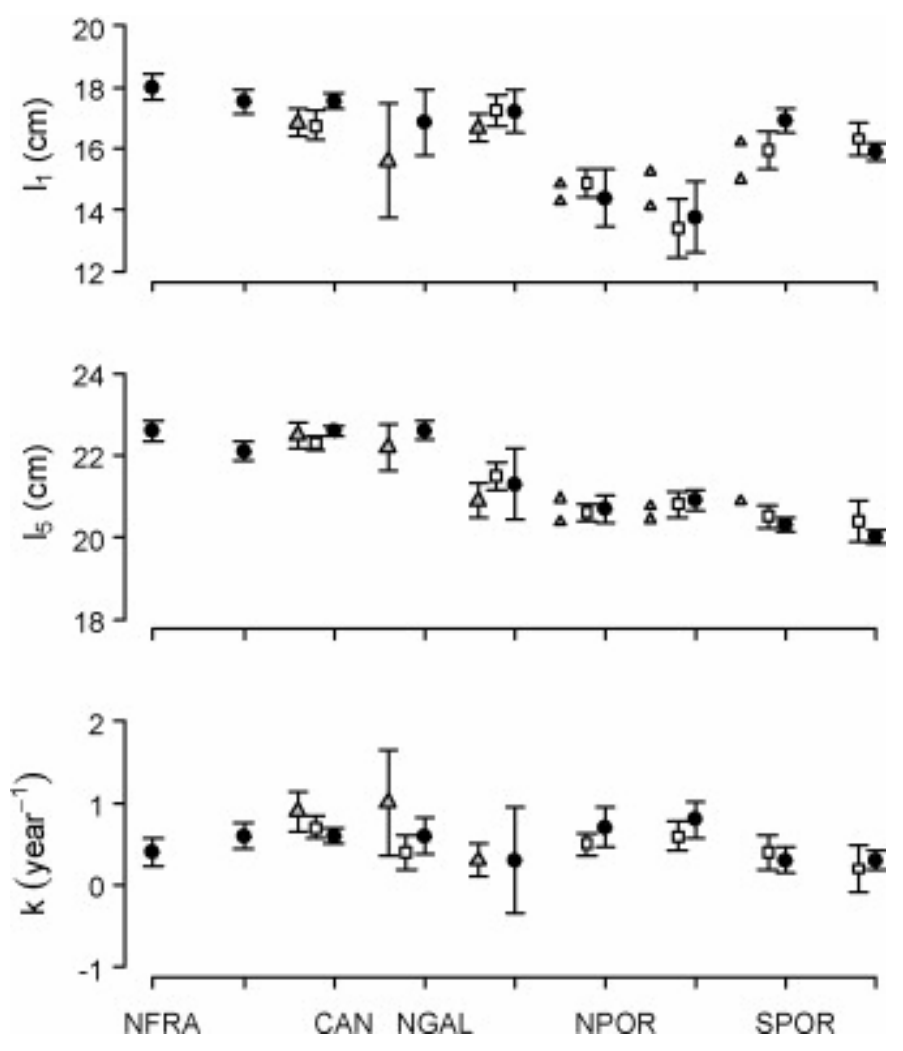

Fig. 5. Variations in growth parameters for each area within the Iberian - Biscay waters in 1986 - 1993 (triangles), 1996 - 1999 (squares) and 2000 - 2005 (circles). Bars represent $95 \%$ inference intervals for the parameters. Smaller triangles represent the mean length of age 1 and age 5 sardine in Portuguese surveys from the 1980s. For the Gulf of Cadiz $1996-$ 1999 and south Galicia $2000-2005, l_{1}$ and $I_{5}$ represent the predicted lengths-at-age 1 and 5 and $\mathrm{k}$ the slope parameter of linear regression models. 


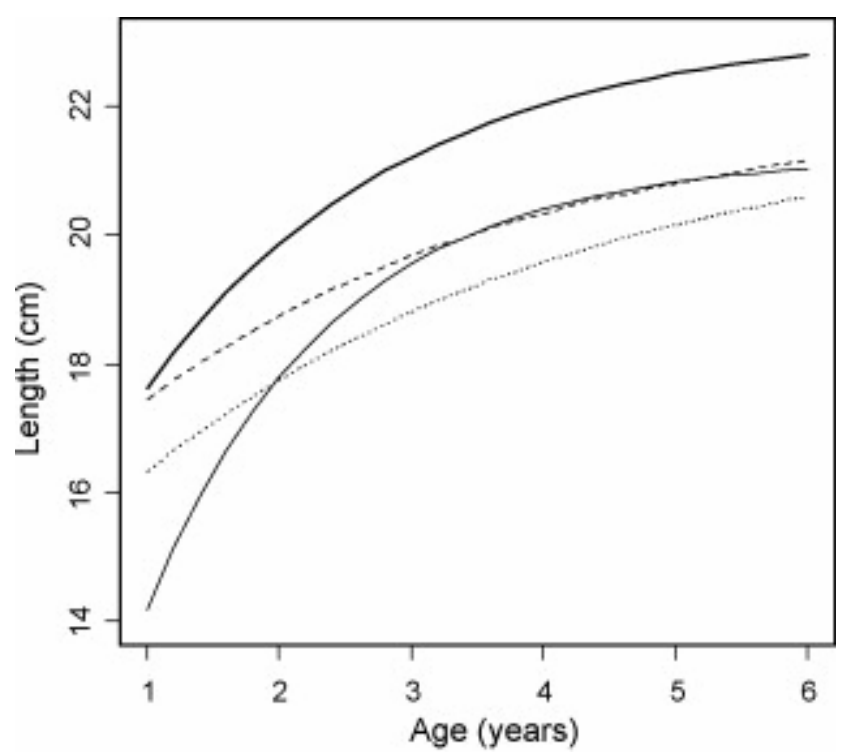

Fig. 6. Von Bertalanffy growth curves fitted to pooled data from spring surveys from North Iberia - Biscay (thick solid line), South Galicia (dashed line), West Portugal (thin solid line) and South Iberia (dotted line), in the period 2000 - 2005.
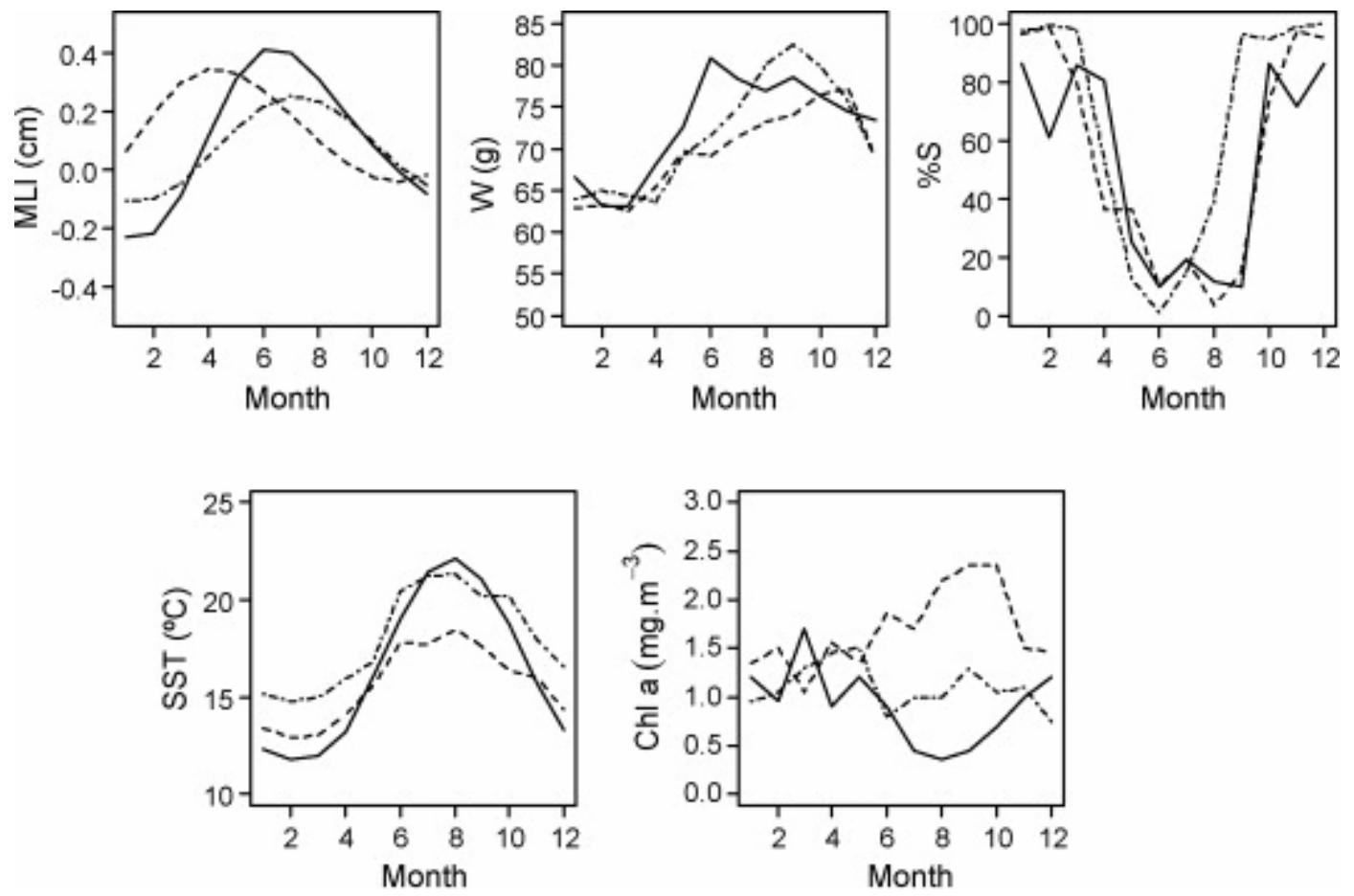

Fig. 7. Seasonal variation of sardine monthly length increment at-age-2 (MLI), mean weight of $20-20.9 \mathrm{~cm}$ individuals (W), percentage of fish spawning (\%S), sea surface temperature (SST) and Chlorophyll a (Chl a) in the Cantabrian Sea (full line), north Portugal (dashed line) and south Portugal (dotted-dashed line), based on pooled market samples from 2004 and 2005. 